\title{
Facile Synthesis of Bis-Dicyanovinylidene-End-Capped Push-Pull Molecules as Panchromatic Absorbers
}

\author{
Tainan Duan, ${ }^{\dagger, \mathrm{a}, \mathrm{b}}$ Ru-Ze Liang, ${ }^{\dagger, c}$ Yi-Fang Pai, ${ }^{\mathrm{c}}$ Kaili Wang, ${ }^{\mathrm{a}, \mathrm{d}}$ Cheng \\ Zhong, ${ }^{*}$ Shirong Lu, ${ }^{* a}$ Donghong Yu ${ }^{* b, f}$ \\ ${ }^{a}$ Chongqing Institute of Green and Intelligent Technology, Chinese Academy of Sciences,
} Chongqing 400714, China. E-mail: lushirong@ cigit.ac.cn.

${ }^{b}$ Department of Chemistry and Bioscience, Aalborg University, Aalborg, DK 9220, Denmark E-mail: yu@bio.aau.dk.

${ }^{c}$ Physical Sciences and Engineering Division, KAUST Solar Center (KSC), King Abdullah University of Science and Technology (KAUST), Thuwal 23955-6900, Saudi Arabia.

${ }^{d}$ College of Chemistry and Chemical Engineering, Chongqing University, Chongqing 400044, PR China.

${ }^{e}$ Hubei Key Laboratory on Organic and Polymeric Opto-electronic Materials, College of Chemistry and Molecular Sciences, Wuhan University, Wuhan 430072, China. E-mail: zhongcheng@whu.edu.cn.

${ }^{f}$ Sino-Danish Centre for Education and Research, Aarhus, DK 8000, Denmark.

\begin{abstract}
A new $\pi$-conjugated building block containing bis-dicyanovinylidene as an end-capping group has been explored for the development of n-type organic semiconductors. This building block can be easily obtained from commercialized 2,3-thiophenedicarboxaldehyde and introduced into a $\pi$-conjugated system in
\end{abstract}


high-yield. By using indaceno[1,2-b:5,6-b']dithiophene (IDT) as the core moiety, an A- $\pi$-D- $\pi$-A molecule with up to 8 cyano- groups (DH8CN) was firstly synthesized and employed as an electron-accepting material in bulk-heterojunction organic solar cells. Preliminary organic cell fabrication gave a $1.1 \%$ power conversion efficiency with PTB7-Th and DH8CN as active layer, show the potential of this bis-dicyanovinylidene group in organic photovoltaics.

Key word: electron acceptor, dicyanovinylidene, end-capping group, organic photovoltaics, photovoltaic performances, device fabrication.

\section{Introduction}

In recent years, electron-deficient $\pi$-conjugated building blocks have regained their popularity due to their capability of producing highly polarized organic semi-conductive molecules that could potentially be used in electronic devices, such as organic field-effect transistors (OFETs) [1, 2] or organic photovoltaics (OPVs) [3, 4]. Especially in the field of OPV research, small-molecule (SM) acceptors that can replace fullerenes (e.g. $\mathrm{PC}_{61} \mathrm{BM}$ or $\left.\mathrm{PC}_{71} \mathrm{BM}\right)$ in bulk-heterojunction $(\mathrm{BHJ})$ solar cells with polymer donors are attracting significant attention in light of the notable device efficiencies achievable with a few recently reported systems. [5-7] In short, the tunable visible absorption and electronics (i.e. Highest Occupied Molecular Orbital (HOMO) and Lowest Unoccupied Molecular Orbital (LUMO) levels) of SM acceptors, and their relative ease of synthetic access in scalable proportions, are 
undisputable benefits when compared with fullerenes.

Unfortunately, even though thousands of researchers are trying to develop high-performance electron accepting materials to replace PCBM series as non-fullerene electron-acceptors, the outstanding results are quite limited due to the difficulty of molecular engineering for drastically lowering the LUMO energy level [8, 9]. To introduce electron-withdrawing groups (EWGs) into $\pi$-conjugated systems was widely used and recognized as one of the most effective strategies to meet this target. But available EWGs are far from sufficient compared with the countless building blocks that possess electron-donating groups (EDGs) [10-14]. Accordingly, the design and synthesis novel EWGs to further open up the boundary of electron-transporting materials is of interest.

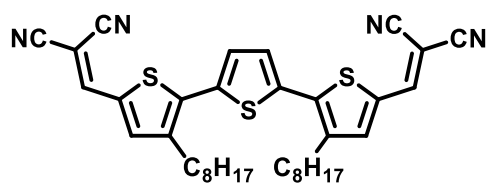

DCN3T
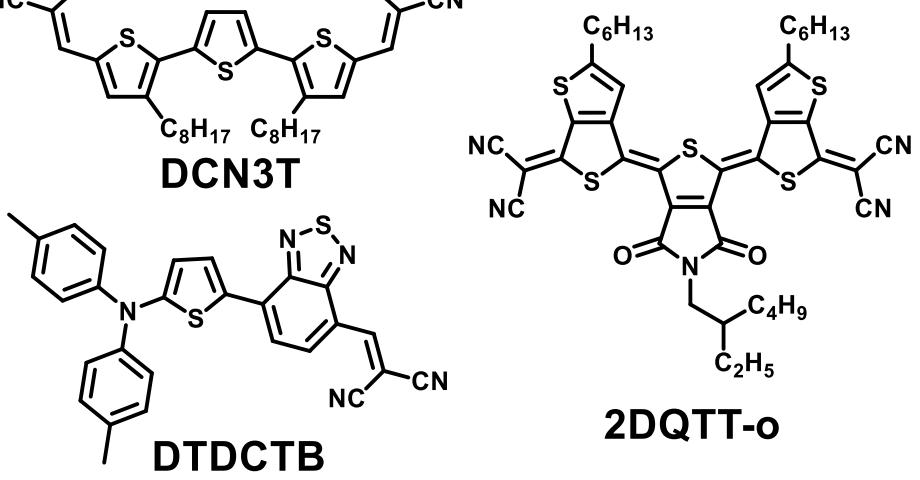

Figure 1. Representative organic semiconductors containing dicyanovinylidene unit $[4,15,16]$

As a classic EWG, the dicyanovinylidene (DCV) moiety achieved dominant success in constructing excellent materials for OFET [17]. But as to OPV, especially for electron-accepting materials in OPV, DCV still possess huge unrealized potential. To acquire favourable low-lying LUMO energy level, usually more than one DCV 
were needed which were attached to the same aromatic ring to form a highly electron-deficient end-capping group. Yet only very few synthetic routes were reported to obtain such structures and none of them can be easily performed with concision and high yield [18-20].

Herein, we report a facile synthesis of push-pull D-A chromophores containing a novel designed building-block in which up to two DCV moieties were directly connected to one thiophene ring as an electron-accepting group. Photo-, electro-physical properties and the preliminary results on their function as non-fullerene electron-acceptors in OPVs are also presented.

\section{Experimental section}

\section{Equipments and materials}

All reactions were performed under nitrogen atmosphere and solvents were purified and dried from appropriate drying agents using standard techniques prior to use. Reagents available from commercial sources were used without further purification unless otherwise stated. Flash chromatography was performed by using Silicycle Silica Flash P60 (particle size 40-63 $\mu \mathrm{m}, 60 \AA$ A, 230-400 mesh) silica gel. Silica gel on TLC-PET foils from VWR was used for TLC. All compounds were characterized by NMR spectroscopy on a Bruker Avance III Ultrashield Plus instruments $(600 \mathrm{MHz})$. The spectra were referenced to the internal standard TMS. High-resolution mass spectrometry (HRMS) data was recorded using a Thermo Scientific-LTQ Velos Orbitrap MS. Note: Spectroscopy-grade $\mathrm{CHCl}_{3}$ was filtered through basic alumina prior to use in order to suppress solvent acidity and avoid 
undesired protonation reactions that may influence the spectral absorption of the molecular acceptors described in this study. Compounds T1 [21] and 6 [22] were prepared according to previously report procedures.

\section{Synthesis}

\section{3,5'-dioctyl-2,2'-bithiophene (T2):}

In a pre-dried Schlenk tube, T1 (3.60 g, $10.00 \mathrm{mmol})$, 2-bromo-3-octylthiophene (2.80 g, $10.20 \mathrm{mmol})$, and $\mathrm{Pd}\left(\mathrm{PPh}_{3}\right)_{4}(580 \mathrm{mg}, 0.50 \mathrm{mmol})$ were dissolved with degassed toluene $(60 \mathrm{~mL})$. The mixture was heated at $110{ }^{\circ} \mathrm{C}$ for $24 \mathrm{~h}$ under argon atmosphere. The reaction mixture was allowed to cool down to room temperature, the organic layer was washed with brine, extracted with hexane, dried over $\mathrm{Na}_{2} \mathrm{SO}_{4}$, and then concentrated under reduced pressure. The crude product was purified by column chromatography over $\mathrm{SiO}_{2}$ using hexanes. The solvent was removed by rotary evaporation, affording compound T2 as a yellow oil (3.12 g, 80\%). ${ }^{1} \mathrm{H}$ NMR (600 $\left.\mathrm{MHz}, \mathrm{CHCl}_{3}, \delta \mathrm{ppm}\right): 7.15(\mathrm{~d}, J=5.4 \mathrm{~Hz}, 1 \mathrm{H}), 6.94-6.92(\mathrm{~m}, 2 \mathrm{H}), 6.74(\mathrm{~d}, J=3.6 \mathrm{~Hz}$, $1 \mathrm{H}), 2.83(\mathrm{t}, J=7.8,2 \mathrm{H}), 2.75(\mathrm{t}, J=7.8 \mathrm{~Hz}, 2 \mathrm{H}), 1.74-1.62(\mathrm{~m}, 4 \mathrm{H}), 1.42-1.28(\mathrm{~m}$, 20H), 0.92-0.89 (m, 6H). ${ }^{13} \mathrm{C}$ NMR (150 MHz, $\left.\mathrm{CHCl}_{3}, \delta \mathrm{ppm}\right):$ 146.09, 139.04, $133.63,131.19,129.84,125.61,124.28,123.18,31.96,31.94,31.69,30.80,30.19$, 29.60, 29.49, 29.41, 29.34, 29.31, 29.23, 29.19, 22.75, 22.74, 14.18, 14.17. HRMS: calcd. for $\mathrm{C}_{24} \mathrm{H}_{38} \mathrm{~S}_{2}[\mathrm{M}+\mathrm{H}]^{+}:$390.24877, found 390.24809.

\section{$3,4^{\prime}, 5^{\prime \prime}$-trioctyl-2,2':5',2'-terthiophene (T3):}

In a pre-dried Schlenk tube, a solution of T2 $(2.50 \mathrm{~g}, 6.40 \mathrm{mmol})$ in anhydrous THF (40 mL) was cooled to $-78{ }^{\circ} \mathrm{C}$. A solution of $\mathrm{n}$-BuLi (2.5 M in THF, $2.9 \mathrm{~mL}, 7.25$ 
mmol) was added dropwise, and the mixture was stirred for $1 \mathrm{~h}$ at $-78{ }^{\circ} \mathrm{C}$. Next, trimethyltin chloride in THF $(1.0 \mathrm{M}, 8.0 \mathrm{~mL}, 8.00 \mathrm{mmol})$ was added to the mixture in one portion. The cooling bath was then removed, the mixture was allowed to warm to room temperature, and was stirred overnight. The reaction was quenched with water $(60 \mathrm{~mL})$ and the aqueous phase was extracted with $\mathrm{CHCl}_{3}(2 \times 50 \mathrm{~mL})$. The organic phase was collected, dried over $\mathrm{Na}_{2} \mathrm{SO}_{4}$, concentrated under reduced pressure, affording tin intermediate as a yellow oil $(3.33 \mathrm{~g}, 94 \%)$ and used to synthesize $\mathbf{T 3}$ without further purification. Following the similar procedure that synthesize T2, T3 was obtained as an orange oil $(2.10 \mathrm{~g}, 75 \%){ }^{1} \mathrm{H} \mathrm{NMR}\left(600 \mathrm{MHz}, \mathrm{CDCl}_{3}, \delta \mathrm{ppm}\right)$ : $7.17(\mathrm{~d}, \mathrm{~J}=4.8 \mathrm{~Hz}, 1 \mathrm{H}), 6.96-6.94(\mathrm{~m}, 3 \mathrm{H}), 6.75(\mathrm{~d}, \mathrm{~J}=3.6 \mathrm{~Hz}, 1 \mathrm{H}), 2.85-2.74(\mathrm{~m}$, $6 \mathrm{H}), 1.75-1.64(\mathrm{~m}, 6 \mathrm{H}), 1.44-1.29(\mathrm{~m}, 30 \mathrm{H}), 0.93-0.89(\mathrm{~m}, 9 \mathrm{H}) .{ }^{13} \mathrm{C} \mathrm{NMR}(150 \mathrm{MHz}$, $\left.\mathrm{CDCl}_{3}, \delta \mathrm{ppm}\right): 146.18,139.46,139.16,133.64,133.33,131.10,130.71,130.06$, $128.60,125.46,124.36,123.42,31.95,31.92,31.67,30.75,30.66,30.19,29.60,29.48$, 29.39, 29.33, 29.29, 29.21, 22.73, 22.72, 14.16. HRMS (+APCI, m/z): calcd. for $\mathrm{C}_{36} \mathrm{H}_{56} \mathrm{~S}_{3}[\mathrm{M}+\mathrm{H}]^{+}:$585.36169, found 585.36243.

\section{Trimethyl(3,4',5'-trioctyl-[2,2':5',2'-terthiophen]-5-yl)stannane (5):}

Following the similar procedure of preparing stannylated T2, 5 was obtained as a brown oil and used without further purification or characterization $(1.83 \mathrm{~g}, 97 \%)$.

5'-bromo-4'-octyl-[2,2'-bithiophene]-4,5-dicarbaldehyde (2):

In a pre-dried Schlenk tube, 2,3-thiophenedicarboxaldehyde (1.40 g, $10.0 \mathrm{mmol})$, 2-bromo-3-octylthiophene (5.51 g, $20.0 \mathrm{mmol}), \operatorname{AgF}(2.54 \mathrm{~g}, 20 \mathrm{mmol})$, and $\mathrm{Pd}(\mathrm{PhCN})_{2} \mathrm{Cl}_{2}(307 \mathrm{mg}, 0.8 \mathrm{mmol})$ were dissolved in degassed DMSO (50 mL) (AgF 
was suspended in solution). The mixture was heated at $60{ }^{\circ} \mathrm{C}$ for $8 \mathrm{~h}$ under argon atmosphere. Then the reaction mixture was allowed to cool down to room temperature, the organic layer was washed with brine, extracted with ethyl acetate $(3 \times 50 \mathrm{~mL})$, dried over $\mathrm{Na}_{2} \mathrm{SO}_{4}$, and then concentrated under reduced pressure. The crude product was purified by column chromatography over $\mathrm{SiO}_{2}$ using hexanes/ $\mathrm{CH}_{2} \mathrm{Cl}_{2}(1: 2)$ as the eluent. The solvent was removed by rotary evaporation, affording compound $\mathbf{2}$ as an orange solid (1.65 g, 40\%). ${ }^{1} \mathrm{H}$ NMR (600 MHz, $\left.\mathrm{CHCl}_{3}, \delta \mathrm{ppm}\right): 10.46$ (s, 1H), 10.35 (s, 1H), $7.56(\mathrm{~s}, 1 \mathrm{H}), 7.10(\mathrm{~s}, 1 \mathrm{H}), 2.59(\mathrm{t}, J=7.8,2 \mathrm{H}), 1.64-1.59(\mathrm{~m}, 2 \mathrm{H}), 1.38-1.30$ (m, 10H), $0.91(\mathrm{t}, J=7.2,3 \mathrm{H}) .{ }^{13} \mathrm{C} \mathrm{NMR}\left(150 \mathrm{MHz}, \mathrm{CHCl}_{3}, \delta \mathrm{ppm}\right):$ 184.28, 181.93, $145.22,144.49,144.29,143.99,134.20,127.47,124.68,111.99,31.87,29.58,29.52$, 29.35, 29.23, 29.22, 22.69, 14.14. HRMS (+APCI, m/z): calcd. for $\mathrm{C}_{18} \mathrm{H}_{21} \mathrm{BrO}_{2} \mathrm{~S}_{2}$ $[\mathrm{M}+\mathrm{H}]^{+}:$414.39545, found 414.39601.

\section{5-bromothiophene-2,3-dicarbaldehyde (3):}

Bromine (4.79 g, $30.0 \mathrm{mmol})$ was added slowly into a solution of 2,3-thiophenedicarboxaldehyde $(1.40 \mathrm{~g}, 10.0 \mathrm{mmol})$ in chloroform $(30 \mathrm{~mL})$ at room temperature, and the solution was stirred overnight under room temperature. The organic phase was then washed with cold aqueous solution of $\mathrm{Na}_{2} \mathrm{~S}_{2} \mathrm{O}_{3}$ to remove redundant bromine, and extracted with $\mathrm{CHCl}_{3}(2 \times 50 \mathrm{~mL})$. The organic phase was collected, dried over $\mathrm{Na}_{2} \mathrm{SO}_{4}$, and concentrated under reduced pressure. The crude product was purified by column chromatography over $\mathrm{SiO}_{2}$ using hexanes $/ \mathrm{CH}_{2} \mathrm{Cl}_{2}$ (1:4) as the eluent. The solvent was removed by rotary evaporation, affording compound 8 as an off-white solid (1.73 g, yield: 73\%). ${ }^{1} \mathrm{H}$ NMR $\left(600 \mathrm{MHz}, \mathrm{CDCl}_{3}, \delta\right.$ 
ppm): 10.39 (s, 1H), 10.28 (s, 1H), 7.61 (s, 1H). $\left.{ }^{13} \mathrm{C} \mathrm{NMR} \mathrm{(150} \mathrm{MHz,} \mathrm{CDCl}_{3}, \delta \mathrm{ppm}\right)$ : 183.28, 181.37, 148.46, 143.65, 132.43, 123.93. HRMS (+APCI, m/z): calcd. for $\mathrm{C}_{6} \mathrm{H}_{3} \mathrm{BrO}_{2} \mathrm{~S}[\mathrm{M}+\mathrm{H}]^{+}:$218.91099, found 218.91083.

2,2'-((5'-bromo-4'-octyl-[2,2'-bithiophene]-4,5-diyl)bis(methanylylidene))dimalonon itrile (4):

Compound 2 (800 mg, $1.93 \mathrm{mmol})$ and malononitrile (1.27 g, $19.3 \mathrm{mmol})$ were dissolved in $20 \mathrm{~mL}$ anhydrous $\mathrm{CHCl}_{3}$ (malononitrile was only partially dissolved in $\mathrm{CHCl}_{3}$ ). To the solution, catalytic amount of basic $\mathrm{Al}_{2} \mathrm{O}_{3}$ powder was added and the mixture was heated at $50{ }^{\circ} \mathrm{C}$ for $12 \mathrm{~h}$ under argon atmosphere. Then the reaction mixture was allowed to cool down to room temperature, the solution was washed with brine, extracted with $\mathrm{CHCl}_{3}(3 \times 50 \mathrm{~mL})$, dried over $\mathrm{Na}_{2} \mathrm{SO}_{4}$, and then concentrated under reduced pressure. The crude product was purified by recrystallization in methanol, affording compound 4 as a red solid (798 mg, yield: $81 \%$ ). ${ }^{1} \mathrm{H}$ NMR (600 $\left.\mathrm{MHz}, \mathrm{CDCl}_{3}, \delta \mathrm{ppm}\right): 8.04(\mathrm{~s}, 1 \mathrm{H}), 7.91(\mathrm{~s}, 1 \mathrm{H}), 7.87(\mathrm{~s}, 1 \mathrm{H}), 7.22(\mathrm{~s}, 1 \mathrm{H}), 2.61(\mathrm{t}, J=$ 7.8, 2H), 1.64-1.61 (m, 2H), 1.38-1.28 (m, 10H), $0.91(\mathrm{t}, J=7.2,3 \mathrm{H}) .{ }^{13} \mathrm{C}$ NMR $(150$ $\left.\mathrm{MHz}, \mathrm{CHCl}_{3}, \delta \mathrm{ppm}\right): 147.41,146.52,144.87,144.51,139.71,136.85,132.84,129.28$, $121.78,114.79,113.47,112.80,112.70,111.94,87.00,80.73,31.86,29.63,29.57$, 29.32, 29.24, 29.22, 22.66, 14.13. HRMS (+APCI, m/z): calcd. for $\mathrm{C}_{24} \mathrm{H}_{21} \mathrm{BrN}_{4} \mathrm{~S}_{2}$ $[\mathrm{M}+\mathrm{H}]^{+}:$509.04638, found 509.04655.

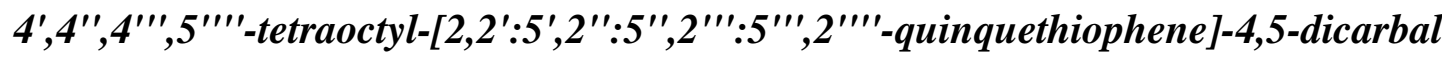
dehyde (7): 
In a pre-dried Schlenk tube, 2 (600 mg, $1.45 \mathrm{mmol}), 5(1.30 \mathrm{~g}, 1.74 \mathrm{mmol})$, and $\mathrm{Pd}\left(\mathrm{PPh}_{3}\right)_{4}(138 \mathrm{mg}, 0.12 \mathrm{mmol})$ were dissolved with degassed toluene $(50 \mathrm{~mL})$. The mixture was heated at $110{ }^{\circ} \mathrm{C}$ for $24 \mathrm{~h}$ under argon atmosphere. The reaction mixture was allowed to cool down to room temperature, and then concentrated under reduced pressure. The crude product was purified by column chromatography over $\mathrm{SiO}_{2}$ using hexanes $/ \mathrm{CH}_{2} \mathrm{Cl}_{2}(1: 2)$ as the eluent. The solvent was removed by rotary evaporation, affording compound 7 as a red solid (1.02 g, 77\%). ${ }^{1} \mathrm{H}$ NMR (600 MHz, $\mathrm{CHCl}_{3}, \delta$ ppm): 10.46 (s, 1H), 10.38 (s, 1H), 7.62 (s, 1H), 7.24 (s, 1H), 7.03 (s, 1H), 6.99 (s, $1 \mathrm{H}), 6.98(\mathrm{~d}, \mathrm{~J}=3.6,1 \mathrm{H}), 6.76(\mathrm{~d}, \mathrm{~J}=3.6,1 \mathrm{H}), 2.86-2.76(\mathrm{~m}, 8 \mathrm{H}), 1.74-1.66(\mathrm{~m}, 8 \mathrm{H})$, 1.44-1.31 (m, 40H), 0.93-0.89 (m, 12H). ${ }^{13} \mathrm{C} \mathrm{NMR}\left(150 \mathrm{MHz}, \mathrm{CHCl}_{3}, \delta \mathrm{ppm}\right): 184.14$, $181.61,146.26,145.79,144.35,143.98,140.50,139.65,139.15,133.86,133.16$ $132.75,132.34,131.87,131.69,131.61,129.64,129.16,128.45,125.42,124.44$, $124.37,31.99,31.96,31.67,30.63,30.51,30.35,30.20,29.72,29.69,29.62,29.53$, 29.43, 29.40, 29.34, 29.26, 22.78, 22.76, 14.20. HRMS: calcd. for $\mathrm{C}_{54} \mathrm{H}_{76} \mathrm{O}_{2} \mathrm{~S}_{5}$ $[\mathrm{M}+\mathrm{H}]^{+}:$917.45216, found 917.45228 .

5,5'-(4,4,9,9-tetrakis(2-ethylhexyl)-4,9-dihydro-s-indaceno[1,2-b:5,6-b']dithiophene -2,7-diyl)bis(thiophene-2,3-dicarbaldehyde) (8):

In a pre-dried Schlenk tube, 3 (523 mg, $2.40 \mathrm{mmol}), 6$ (1.04 g, $1.00 \mathrm{mmol})$, and $\mathrm{Pd}\left(\mathrm{PPh}_{3}\right)_{4}(220 \mathrm{mg}, 0.19 \mathrm{mmol})$ were dissolved with degassed toluene $(50 \mathrm{~mL})$. The mixture was heated at $110{ }^{\circ} \mathrm{C}$ for $36 \mathrm{~h}$ under argon atmosphere. The reaction mixture was allowed to cool down to room temperature, and then concentrated under reduced pressure. The crude product was purified by column chromatography over $\mathrm{SiO}_{2}$ using 
hexanes $/ \mathrm{CH}_{2} \mathrm{Cl}_{2}(1: 2)$ as the eluent. The solvent was removed by rotary evaporation, affording compound 8 as a crimson solid (882 mg, 89\%). ${ }^{1} \mathrm{H} \mathrm{NMR}\left(600 \mathrm{MHz}, \mathrm{CHCl}_{3}\right.$, $\delta$ ppm): $10.47(\mathrm{~s}, 2 \mathrm{H}), 10.40(\mathrm{~s}, 2 \mathrm{H}), 7.68-7.67(\mathrm{~m}, 2 \mathrm{H}), 7.39(\mathrm{~s}, 2 \mathrm{H}), 7.33-7.32(\mathrm{~m}$, 2H), 2.03-2.00 (m, 8H), 1.03-0.86 (m, 32H), 0.72-0.54 (m, 28H). ${ }^{13} \mathrm{C}$ NMR (150 MHz, $\left.\mathrm{CHCl}_{3}, \delta \mathrm{ppm}\right): 184.51,181.79,(156.53,156.49,156.44,156.36), 153.54,147.31$, $(144.72,144.68,144.65), 144.55,143.69,135.81,123.94,(122.29,122.22,122.17$, $122.11,122.03,121.99,121.92), 114.67,(54.30,54.28,54.24),(44.00,43.88,43.44$, 43.38), (35.16, 35.11, 35.07, 35.01), (34.30, 34.26, 34.20, 34.18), (33.90, 33.86, 33.77, 33.74), 28.67, 28.56, (28.17, 28.15, 28.12), (27.47, 27.44), 27.31, 27.17, 27.01, 22.85, $22.79,22.76,14.18,14.06,10.75,10.62,10.36,10.32,10.30$. HRMS: calcd. for $\mathrm{C}_{60} \mathrm{H}_{78} \mathrm{O}_{4} \mathrm{~S}_{4}[\mathrm{M}+\mathrm{H}]^{+}:$991.48557, found 991.48533.

\section{DH4CN and DH8CN}

General procedure: Aldehyde (7 or 8, 1.0 equiv.) and malononitrile (10.0 equiv. for 7, 20 equiv. for 8 ) were dissolved in anhydrous $\mathrm{CHCl}_{3}(20 \mathrm{~mL}$ ) (malononitrile was only partially dissolved in $\mathrm{CHCl}_{3}$ ). To the solution, basic $\mathrm{Al}_{2} \mathrm{O}_{3}$ powder (40.0 equiv.) was added and the mixture was heated at $50{ }^{\circ} \mathrm{C}$ for $24 \mathrm{~h}$ under argon atmosphere. Then the reaction mixture was allowed to cool down to room temperature, the solution was washed with brine, extracted with ethyl acetate $(3 \times 30 \mathrm{~mL})$, dried over $\mathrm{Na}_{2} \mathrm{SO}_{4}$, and then concentrated under reduced pressure. The crude product was purified by column chromatography over $\mathrm{SiO}_{2}$ using hexanes/ethyl acetate (6:1) as the eluent. The solvent was removed by rotary evaporation, affording final product

\section{DH4CN or DH8CN.}


DH4CN: Dark green solid (380 mg, 64\%). IR (powder, $\mathrm{cm}^{-1}$ ): 3056, 3032, 2955, 2922, 2852, 2222, 1565, 1519, 1486, 1423, 1461, 1402, 1338, 1259, 1232, 1200, 1173, 1149, 999, 918, 829, 612. ${ }^{1} \mathrm{H}$ NMR (600 MHz, $\mathrm{CHCl}_{3}, \delta$ ppm): 8.08 (s, 1H), 7.87 (s, 1H), $7.86(\mathrm{~s}, 1 \mathrm{H}), 7.35(\mathrm{~s}, 1 \mathrm{H}), 7.09(\mathrm{~s}, 1 \mathrm{H}), 7.00(\mathrm{~s}, 1 \mathrm{H}), 6.98(\mathrm{~d}, \mathrm{~J}=3.6 \mathrm{~Hz}, 1 \mathrm{H}), 6.77(\mathrm{~d}$, $\mathrm{J}=3.6 \mathrm{~Hz}, 1 \mathrm{H}), 2.86-2.76(\mathrm{~m}, 8 \mathrm{H}), 1.74-1.66(\mathrm{~m}, 8 \mathrm{H}), 1.46-1.31(\mathrm{~m}, 40 \mathrm{H}), 0.92-0.89$ $(\mathrm{m}, 12 \mathrm{H}) .{ }^{13} \mathrm{C} \mathrm{NMR}\left(150 \mathrm{MHz}, \mathrm{CHCl}_{3}, \delta \mathrm{ppm}\right): 146.45,141.02,139.91,138.97$, $136.98,136.27,132.94,132.69,132.17,131.93,131.67,130.07,125.05,124.37$, $113.67,112.99,112.35,84.99,78.21,31.99,31.95,31.91,31.40,30.41,30.20,30.11$, $29.96,29.89,29.81,29.55,29.49,29.46,29.41,29.36,22.77,22.72,14.19,14.17$, 14.13. HRMS: calcd. for $\mathrm{C}_{60} \mathrm{H}_{76} \mathrm{~N}_{4} \mathrm{~S}_{5}[\mathrm{M}+\mathrm{H}]^{+}$: 1013.47463 , found 1013.47396 . Melting point: $117^{\circ} \mathrm{C}$.

DH8CN: Dark green solid (210 mg, 47\%). IR (powder, $\mathrm{cm}^{-1}$ ): 3050, 2955, 2923, 2852, 2224, 1582, 1564, 1533, 1483, 1432, 1404, 1335, 1254, 1204, 1149, 1093, 999, 919, 827, 794, 721, 613. ${ }^{1} \mathrm{H}$ NMR (600 MHz, $\left.\mathrm{CHCl}_{3}, \delta \mathrm{ppm}\right): 8.17-8.16$ (m, 2H), 7.96 (s, 2H), $7.95(\mathrm{~s}, 2 \mathrm{H}), 7.54-7.52(\mathrm{~m}, 2 \mathrm{H}), 2.08-2.06(\mathrm{~m}, 8 \mathrm{H}), 1.00-0.94(\mathrm{~m}, 32 \mathrm{H})$, 0.75-0.58 (m, 28H). ${ }^{13} \mathrm{C}$ NMR (150 MHz, $\left.\mathrm{CHCl}_{3}, \delta \mathrm{ppm}\right)$ : HRMS: calcd. for $\mathrm{C}_{72} \mathrm{H}_{78} \mathrm{~N}_{8} \mathrm{~S}_{4}[\mathrm{M}+\mathrm{H}]^{+}:$1183.53050, found 1183.53361.

\section{Fabrication and measurement of photovoltaic devices}

The organic photovoltaic devices were prepared on glass substrates with ITO (15 $\Omega / \mathrm{sq})$ patterned on the surface (device area: $0.1 \mathrm{~cm}^{2}$ ). Substrates were prewashed with isopropanol to remove organic residues before being sonicated in bath of dilute 
Extran $^{\circledR}$ 300. Samples were rinsed with deionized water for $5 \mathrm{~min}$ before being sonicated (Branson 5510) for 15 min each in successive baths of deionized water, acetone and isopropanol. Next, the samples were dried with pressurized nitrogen before being exposed to a UV-ozone plasma for $15 \mathrm{~min}$. Meanwhile, a precursor solution of zinc acetate dihydrate $(200 \mathrm{mg})$, 2-methoxyethanol (4 mL), and ethanolamine $(55 \mu \mathrm{L})$ was prepared and stirred vigorously in ambient atmosphere for at least $12 \mathrm{~h}$. For the fabrication of direct devices, a thin layer of PEDOT:PSS ( 35nm) (Clevios AL4083) was spun-cast onto the UV-treated substrates, the PEDOT-coated substrates were subsequently annealed on a hot plate at $150{ }^{\circ} \mathrm{C}$ for $15 \mathrm{~min}$, and the substrates were then transferred into the glovebox for active layer deposition. All solutions with the polymer donor PCE10 (purchased from Solarmer) and small molecule acceptors DH8CN were prepared in the glovebox. PCE10 and the molecular acceptors were dissolved in THF, and the solutions were stirred at $50{ }^{\circ} \mathrm{C}$ for at least 4 h. The active layers were spun-cast from the blend solutions at $50{ }^{\circ} \mathrm{C}$ at an optimized spin speed of $4000 \mathrm{rpm}$ for $45 \mathrm{~s}$, using a programmable spin-coater from Specialty Coating Systems (Model G3P-8). The samples were then dried under vacuum for at least $1 \mathrm{~h}$. The samples were placed in a thermal evaporator for evaporation of a $7 \mathrm{~nm}$ thick molybdenum oxide $\left(\mathrm{MoO}_{3}\right)$ layer evaporated at $0.5 \AA$, s, and a $100 \mathrm{~nm}$ thick layer of silver evaporated at $5 \AA$ /s; pressure of less than $2 \times 10^{-6}$ torr. Following electrode deposition, samples underwent $J$ - $V$ testing.

$J-V$ measurements of solar cells were performed in the glovebox with a Keithley 2400 source meter and an Oriel Sol3A Class AAA solar simulator calibrated to AM 1.5 G, 
with a KG-5 silicon reference cell certified by Newport. The external quantum efficiency (EQE) measurements were performed at zero bias by illuminating the device with monochromatic light supplied from a Xenon arc lamp in combination with a dual-grating monochromator. The number of photons incident on the sample was calculated for each wavelength by using a silicon photodiode calibrated by NIST.

\section{Results and discussion}

\section{Synthesis and Characterization}

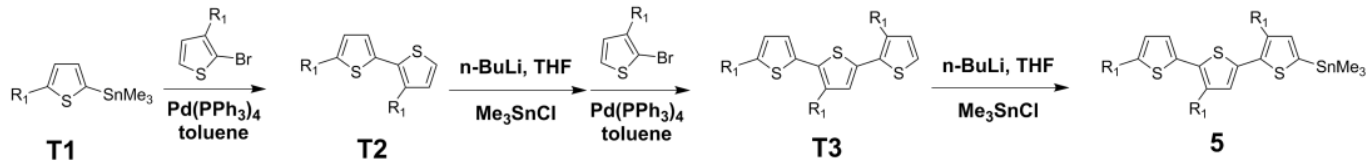

T2
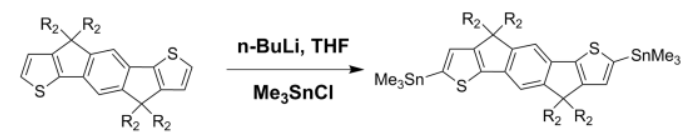

IDT-EH

6
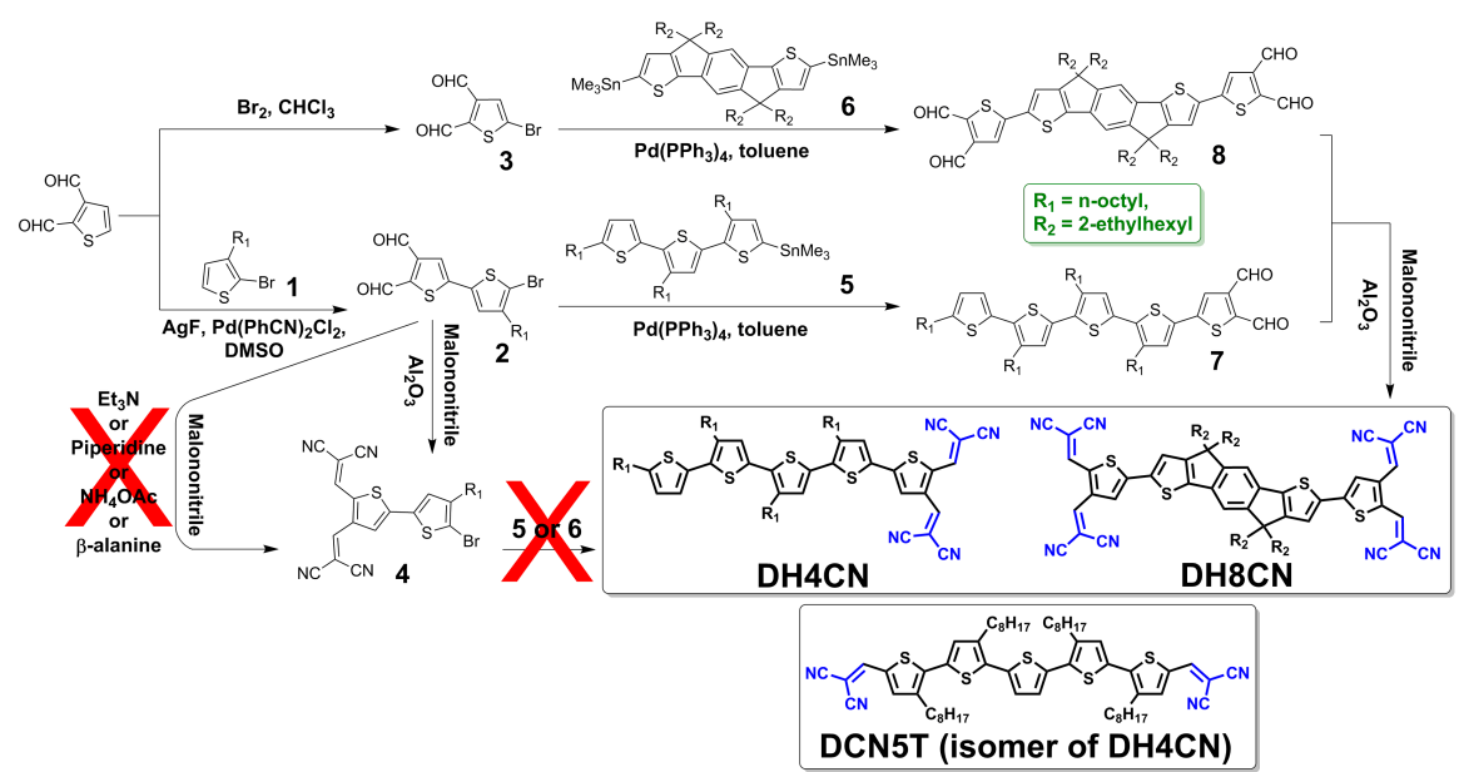

Scheme 1. Synthesis of bis-dicyanovinylidene-end-capped push-pull molecules.

The synthetic route is depicted in Scheme 1. The first key intermediate, bithiophene-dicarboxaldehyde $\mathbf{2}$, was obtained conveniently using a direct oxidative coupling. But synthesizing the bis-dicyanovinylidene compound 4 via a classic 
Knoevenagel condensation reaction was far more challenging than we thought. To the solution of $\mathbf{2}$ in chloroform, several different widely-used catalysts from basic piperidine, pyridine to neutral ammonium acetate, $\beta$-alanine was added respectively [23-25]. But all of them only resulted a brownish to black solution with no sign of major product indicated by TLC examination. Similarly changing the solvent (toluene, acetonitrile, acetic acid, etc.), temperature (refluxing or under r.t.) or the absence of a catalyst were all ineffective strategies. Fortuitously, use of aluminium oxide proved effective for the clean synthesis of $\mathbf{4}$ in high yield and thus $\mathbf{4}$ could be readily purified by a simple recrystallization. Bromo-substituted dicyanovinylidene derivatives were widely-used as synthon in Stille coupling reaction to elongate the $\pi$-conjugate backbones of organic semiconductors [26]. But compound 4 was non-reactive for Stille coupling reaction under several different standard conditions $\left(\mathrm{Pd}_{2}(\mathrm{dba})_{3} / \mathrm{P}(\mathrm{o}-\text { tolyl })_{3} /\right.$ toluene, $\mathrm{Pd}\left(\mathrm{PPh}_{3}\right)_{4} /$ toluene or $\mathrm{Pd}(\mathrm{dppf}) \mathrm{Cl}_{2} /$ toluene $)$. This could be attributed to the extremely electron-deficient behavior of compound $\mathbf{4}$ that made the bromide inert in Pd-catalyzed reactions [27]. Thus we had to go back to intermediate 2 for the elongation of $\pi$-conjugate backbone, and then performed the final Knoevenagel condensation to get the asymmetric D- $\pi$-A molecule DH4CN. By changing core moiety to indaceno[1,2-b:5,6-b']dithiophene (IDT) and $\pi$-linker to thiophene-dicarboxaldehyde $\mathbf{3}$, we also successfully synthesized symmetric A- $\pi$-D- $\pi$-A molecule DH8CN which unprecedentedly contains up to 4 dicyanovinylidene moieties as the terminal group. Notably, although 4 branched alkyl side chains were included in DH8CN, still it shows only moderate solubility in 
regular solvents such as $\mathrm{CHCl}_{3}$ or toluene. Besides, a previously reported molecule DCN5T, an isomer of DH4CN, was also synthesized and used as a reference to make a clearer understanding about this novel EWG [16]. Unfortunately the ${ }^{13} \mathrm{C}$ NMR data of DH8CN was not available due to its relatively poor solubility.

\section{Photophysical and electrochemical Properties}
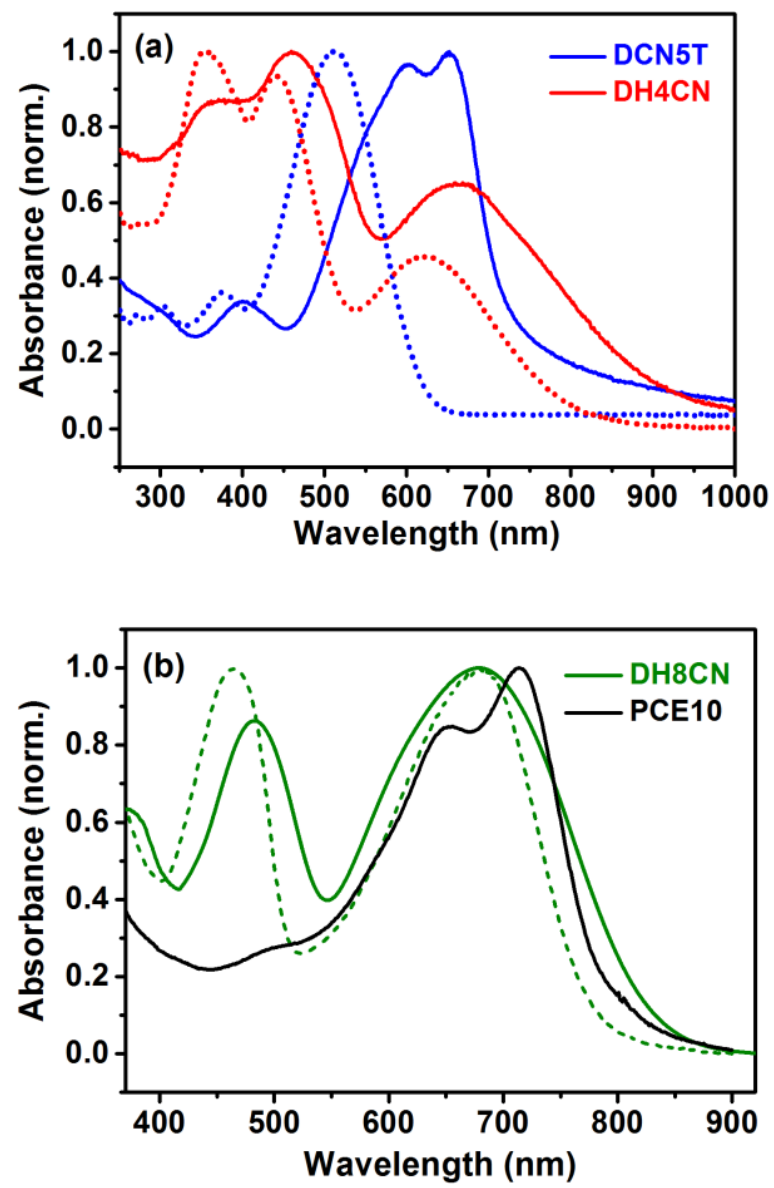

Figure 2. Normalized UV-Vis absorption spectra of (a) DH4CN (red) and DCN5T

(blue); (b) DH8CN (green) and PCE10 (black) in $\mathrm{CHCl}_{3}$ (short dash) and (or) thin films (solid line).

The UV-Vis absorption spectra of target compounds are presented in Figure 2, and the related numeric data are presented in Table 1. As it shows, DH4CN exhibits 
two distinct absorption bands in $\mathrm{CHCl}_{3}$ solution that corresponds to $\pi-\pi^{*}$ transition and intramolecular charge transfer (ICT) respectively. In film, not only are the ICT absorption band intensities significantly enhanced, but also the absorption onset of DH4CN is drastically extended into the near-infrared (NIR) region $(\sim 900 \mathrm{~nm})$ that result in an extremely low optical bandgap (1.40 eV). Meanwhile, DCN5T only shows a medium optical bandgap $(1.70 \mathrm{eV})$. DH8CN shows similar spectra profile with DH4CN, only with stronger ICT absorption due to the introduction of one more bis-dicyanovinylidene group and its A- $\pi$-A structure. But an expected red-shift was not observed in the thin film state for $\mathbf{D H 8 C N}$, which could be attributed to the branched alkyl chains and non-coplanar structure of IDT [28].

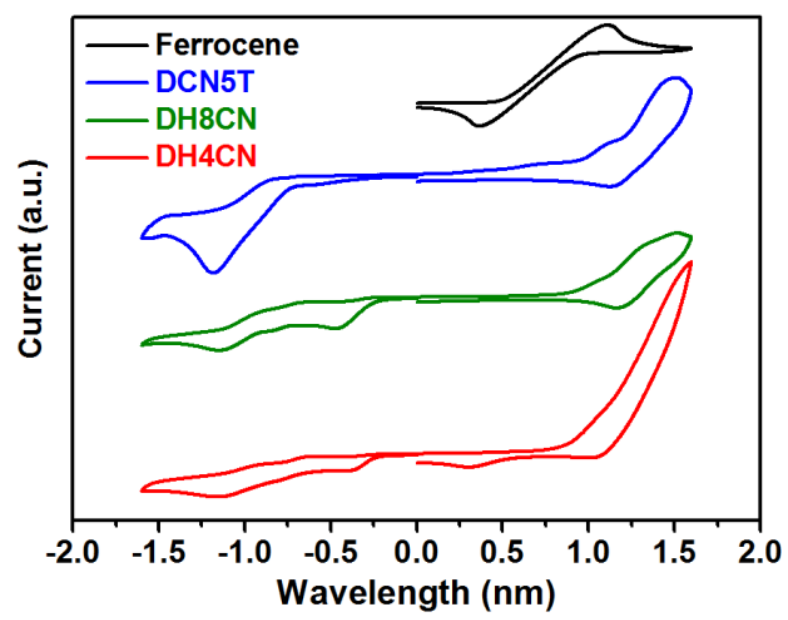

Figure 3. Cyclic voltammograms of DH4CN (red), DH8CN (green) and DCN5T (blue).

Table 1. Optical and Electrochemical Properties of Compounds.

$\begin{array}{ccccccc}\begin{array}{c}\max ^{\mathrm{a}}, \mathrm{nm}\left(\varepsilon, 10^{4} \mathrm{M}^{-1}\right. \\ \left.\mathrm{cm}^{-1}\right)\end{array} & \begin{array}{c}\Delta E_{\mathrm{opt}}^{\mathrm{b}}, \\ \mathrm{eV}\end{array} & \begin{array}{c}E_{\mathrm{ox}}^{\mathrm{c}}, \\ \mathrm{V}\end{array} & \begin{array}{c}E_{\mathrm{red}}^{\mathrm{c}}, \\ \mathrm{V}\end{array} & \begin{array}{c}\mathrm{IP}^{\mathrm{d}}, \\ \mathrm{eV}\end{array} & \begin{array}{c}\mathrm{EA}^{\mathrm{d}}, \\ \mathrm{eV}\end{array} \\ \text { DH4CN } & \begin{array}{c}353(3.62), 442 \\ (3.30), 624(1.60)\end{array} & 1.40 & 0.87 & -0.25 & 5.97 & 4.55 \\ \text { DH8CN } & 355(2.82), 465 & 1.58 & 0.88 & -0.25 & 5.98 & 4.55\end{array}$


(4.20), $680(4.21)$

$\begin{array}{lllllll}\text { DCN5T } & 511(7.63) & 1.70 & 0.98 & -0.75 & 6.08 & 4.05\end{array}$

${ }^{\mathrm{a}}$ Absorption maxima recorded in chloroform. ${ }^{\mathrm{b}}$ Estimated from the absorption onset in film. ${ }^{\mathrm{c}}$ In THF containing $0.1 \mathrm{M} \mathrm{TBAPF}\left(\mathrm{vs} \mathrm{Fc} / \mathrm{Fc}^{+}\right)$at $50 \mathrm{mV} \cdot \mathrm{s}^{-}-1 .{ }^{\mathrm{d}} \mathrm{IP}=\left(\mathrm{E}_{\text {onset, ox }}+4.8\right) \mathrm{eV}, \mathrm{EA}=\left(\mathrm{E}_{\text {onset, }}\right.$ red $+4.8) \mathrm{eV}$

The electrochemical behaviour of the three molecules (DCN5T included) were investigated by cyclic voltammetry $(\mathrm{CV})$ in THF using a three-electrode system. The $\mathrm{Ag} / \mathrm{Ag}^{+}$reference electrode was internally calibrated using the ferrocene/ferrocenium $\left(\mathrm{Fc} / \mathrm{Fc}^{+}\right)$redox couple which is taken to be $4.8 \mathrm{eV}$ relative to the vacuum level. The CV curves are shown in Figure 3 with the data summarized in Table 1. DH4CN gave the onset of reduction potential around $-0.25 \mathrm{~V}$ while its isomer DCN5T merely showed a much shallower onset potential around $-0.75 \mathrm{~V}$. This result clearly confirmed that DH4CN has much higher electron-affinity than DCN5T. And both DH4CN and DH8CN exhibit an EA as low as $4.55 \mathrm{eV}$, indicating they are very strong electron acceptors.

\section{Photovoltaic Performances}



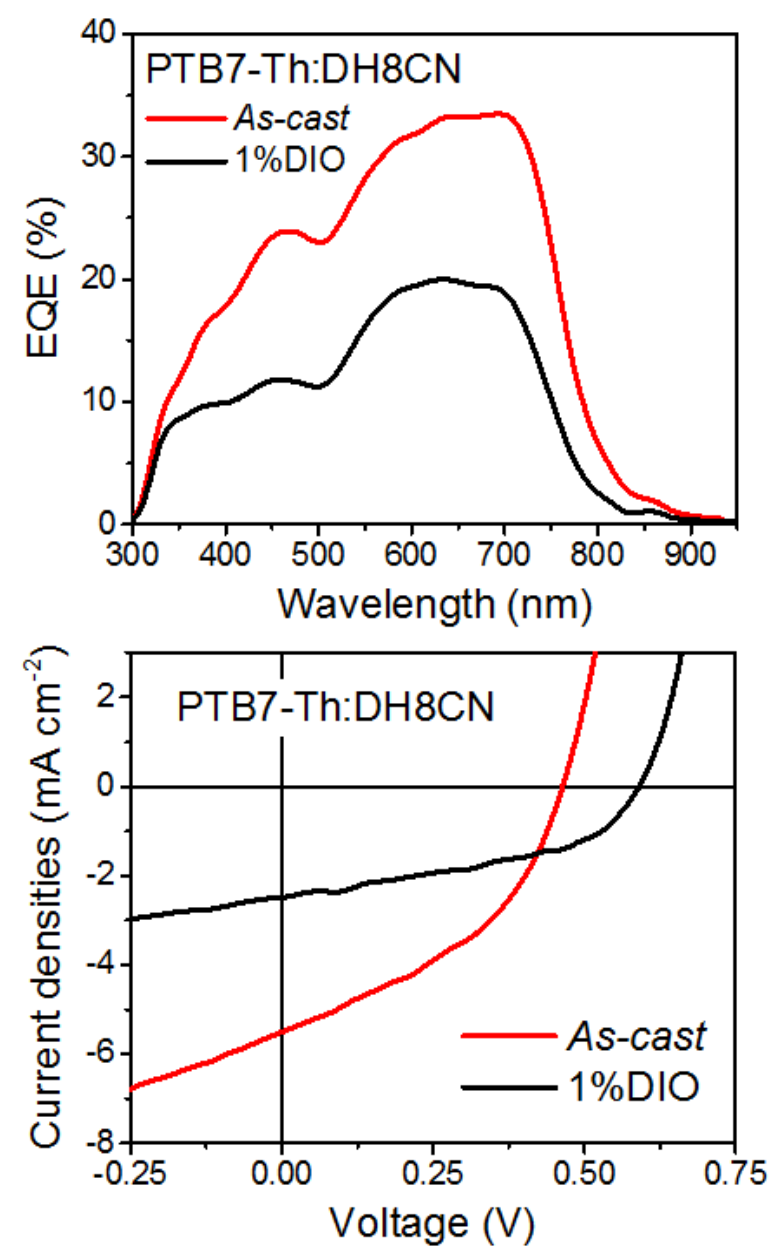

Figure 4. Characteristic J-V curves and EQE spectra of optimized BHJ solar cells fabricated with the polymer donor PTB7-Th (model system), and DH8CN serving as nonfullerene acceptors.

The relatively low EA value combined with the non-planar 3D structure of DH8CN inspired us to evaluate the photovoltaic performance of this highly polarized molecule as non-fullerene acceptor in OPV devices. Thin-film BHJ solar cells were fabricated with the direct structure ITO/ZnO/PTB7-Th:DH8CN/ $\mathrm{MoO}_{3} / \mathrm{Ag}$ (device area: $\left.0.1 \mathrm{~cm}^{2}\right)$, and tested under simulated AM1.5G sun illumination $\left(100 \mathrm{~mW} / \mathrm{cm}^{2}\right)$.

Figure 4 displays the figures of merit of optimized BHJ devices made from blends of PTB7-Th and DH8CN. We note that small-molecule additives, such as 
1,8-diiodooctane (DIO) and 1-chloronaphthalene $(\mathrm{CN})$, have been shown to improve the blend morphologies of BHJ solar cells made with polymer donor and PCBM acceptors and, in turn, device PCEs. It is equally important to note, however, that morphological variations induced by additives can also result in reduced performance figures and that the outcome of these tentative optimization steps remain material system-dependent. As shown in the J-V curve, an "optimized" device made from PTB7-Th and DH8CN blends in THF yield short-circuit current $\left(\mathrm{J}_{\mathrm{SC}}\right)$, open-circuit voltage $\left(\mathrm{V}_{\mathrm{OC}}\right)$, and fill factor $(\mathrm{FF})$ of $5.5 \mathrm{~mA} / \mathrm{cm}^{2}, 0.47 \mathrm{~V}$, and 42 , respectively, leading to a preliminary device performance of $1.1 \%$. Turning to external quantum efficiency (EQE), the spectrum reveals the profile of the conversion from the incident photons to the currents in the PTB7-Th: DH8CN system. Across the region $450-730 \mathrm{~nm}$, the EQE shows $>25 \%$ (max. $~ 33 \%$ peaked at $700 \mathrm{~nm}$ ), suggesting that the PTB7-Th and DH8CN both contribute to acquiring the incident photons.

To examine the potential contributions of morphological effects to the distinct EQE and device efficiency characteristics obtained for PTB7-Th:DH8CN solar cells, we turned to an examination of the aggregation patterns via atomic-force microscopy (AFM). The AFM topography and phase images provided in Figure $\mathbf{S 4}$ shows various extents of aggregation and indicate that the DH8CN acceptor in as-cast and 1\% DIO conditions do not form identical active-layer morphologies with PTB7-Th. The coarser aggregation pattern observed in 1\% DIO condition (RMS roughness: $4.6 \mathrm{~nm}$ ) contrasts with that in as cast (RMS roughness: $3.1 \mathrm{~nm}$ ), and may correlate with a more pronounced degree of phase separation between PTB7-Th and DH8CN (a detailed 
morphology study is beyond the scope of this concise report).

\section{Conclusions}

In conclusion, bis-dicyanovinylidene, a new EWG was designed and synthesized by a facile procedure. And two strong electron acceptors of DH4CN and DH8CN with high electron affinity $(\sim 4.55 \mathrm{eV})$ also have been synthesized accordingly. The photovoltaic performance of $\mathbf{D H 8 C N}$ has been characterized showing promising potential that gave a maximum device of $1.1 \%$. Even though the efficiency can be further improved by optimizing the preparation of a device, our results show a new strategy of molecular design that paves the way to the development of a wider range of systems with tunable electronics and optical spectra.

\section{Author Contributions}

$\dagger$ These authors contributed equally to this work.

\section{Acknowledgements}

We acknowledge financial support from National Natural Science Foundation of China (R52A199Z10, 21702202), Natural Science Foundation of Chongqing (cstc2015jcyjB0628, cstc2017rgzn-zdyfX0030). Financial support from Innovation fund Denmark (INKA-Inks for large-scale processing of polymer solar cells) and Sino-Danish Centre for Education and Research (SDC) are also fully acknowledged. 


\section{References}

1. J. H. Dou, Y. Q. Zheng, Z. F. Yao, T. Lei, X. X. Shen, X. Y. Luo, Z. A. Yu, S. D.

Zhang, G. C. Han, Z. Wang, Y. P. Yi, J. Y. Wang, J. Pei, Adv. Mater. 2015, 27, $8051-8055$

2. B. L. Hu, K. Zhang, C. B. An, W. Pisula, M. Baumgarten, Org. Lett. 2017, 19, 6300-6303.

3. C. Liu, K. Wang, X. Gong, A. J. Heeger, Chem. Soc. Rev. 2016, 45, 4825-4846.

4. C. Zhang, X. Z. Zhu, Accounts Chem. Res. 2017, 50, 1342-1350.

5. S. J. Liu, Z. P. Kan, S. Thomas, F. Cruciani, J. L. Bredas, P. M. Beaujuge, Angew. Chem. Int. Edit. 2016, 55, 12996-13000.

6. D. Meng, D. Sun, C. M. Zhong, T. Liu, B. B. Fan, L. J. Huo, Y. Li, W. S. Jiang, H.

S. Choi, T. Kim, J. Y. Kim, Y. M. Sun, Z. H. Wang, A. J. Heeger, J. Am. Chem. Soc. 2016, $138,375-380$.

7. H. F. Yao, Y. Chen, Y. P. Qin, R. N. Yu, Y. Cui, B. Yang, S. S. Li, K. Zhang, J. H. Hou, Adv. Mater. 2016, 28, 8283-8287.

8. J. T. E. Quinn, J. X. Zhu, X. Li, J. L. Wang, Y. N. Li, J. Mater. Chem. C 2017, 5, 8654-8681.

9. Y. Zhao, Y. L. Guo, Y. Q. Liu, Adv. Mater. 2013, 25, 5372-5391.

10. J. E. Anthony, A. Facchetti, M. Heeney, S. R. Marder, X. W. Zhan, Adv. Mater. 2010, 22, 3876-3892.

11. Z. T. Liu, G. X. Zhang, Z. X. Cai, X. Chen, H. W. Luo, Y. H. Li, J. G. Wang, D. Q. Zhang, Adv. Mater. 2014, 26, 6965-6977. 
12. A. Facchetti, M. H. Yoon, C. L. Stern, H. E. Katz, T. J. Marks, Angew. Chem. Int. Edit. 2003, 42, 3900-3903.

13. Y. Fukutomi, M. Nakano, J. Y. Hu, I. Osaka, K. Takimiya, J. Am. Chem. Soc. 2013, $135,11445-11448$

14. Y. Sakamoto, T. Suzuki, M. Kobayashi, Y. Gao, Y. Fukai, Y. Inoue, F. Sato, S. Tokito, J. Am. Chem. Soc. 2004, 126, 8138-8140.

15. L.-Y. Lin, Y.-H. Chen, Z.-Y. Huang, H.-W. Lin, S.-H. Chou, F. Lin, C.-W. Chen, Y.-H. Liu and K.-T. Wong, J. Am. Chem. Soc., 2011, 133, 15822-15825.

16. Y. S. Liu, J. Y. Zhou, X. J. Wan, Y. S. Chen, Tetrahedron, 2009, 65, 5209-5215.

17. H. Usta, A. Facchetti, T. J. Marks, J. Am. Chem. Soc. 2008, 130, 8580-8581.

18. Y. Ie, K. Nishida, M. Karakawa, H. Tada, A. Asano, A. Saeki, S. Seki, Y. Aso, Chem-Eur. J. 2011, 17, 4750-4758.

19. Y. Ie, K. Nishida, M. Karakawa, H. Tada, Y. Aso, J. Org. Chem. 2011, 76, 6604-6610.

20. Y. Ie, A. Uchida, N. Kawaguchi, M. Nitani, H. Tada, F. Kakiuchi, Y. Aso, Org. Lett. 2016, $18,4320-4323$.

21. F. Lincker, B. Heinrich, R. De Bettignies, P. Rannou, J. Pecaut, B. Grevin, A. Pron, B. Donnio, R. Demadrille, J. Mater. Chem. 2011, 21, 14, 5238-5247.

22. J.-L. Wang, Q.-R. Yin, J.-S. Miao, Z. Wu, Z.-F. Chang, Y. Cao, R.-B. Zhang, J.-Y. Wang, H.-B. Wu, Y. Cao, Adv. Funct. Mater. 2015, 25, 23, 3514-3523.

23. H. Yao, Y. Cui, R. Yu, B. Gao, H. Zhang, J. Hou, Angew. Chem. Int. Edit. 2017, 56, 3045-3049. 
24. T. Horiuchi, H. Miura, S. Uchida, Chem. Comm. 2003, 3036-3037.

25. W. Ni, M. Li, F. Liu, X. Wan, H. Feng, B. Kan, Q. Zhang, H. Zhang, Y. Chen, Chem. Mater. 2015, 27, 6077-6084.

26. C. Steck, M. Franckevičius, S. M. Zakeeruddin, A. Mishra, P. Bäuerle, M. Grätzel, J. Mater. Chem. A 2015, 3, 17738-17746.

27. J. A. Letizia, S. Cronin, R. P. Ortiz, A. Facchetti, M. A. Ratner, T. J. Marks, Chem-Eur. J. 2010, 16, 1911-1928.

28. S. Holliday, R. S. Ashraf, A. Wadsworth, D. Baran, S. A. Yousaf, C. B. Nielsen, C. H. Tan, S. D. Dimitrov, Z. Shang, N. Gasparini, M. Alamoudi, F. Laquai, C. J. Brabec, A. Salleo, J. R. Durrant, I. McCulloch, Nat. Commun. 2016, 7, 11585. 